\title{
IMPROVEMENT OF THE SYSTEM OF REARING PEDIGREE AND REPAIR YOUNG PIGS IN THE CONDITIONS OF MODERN TECHNOLOGIES
}

\author{
Serhii Smyslov ${ }^{1}$ \\ Mykhailo Sokyrko ${ }^{2}$
}

DOI: https://doi.org/10.30525/978-9934-588-15-0-137

\begin{abstract}
The issue of improving the rearing pedigree and repair young pigs in conditions of modern technologies is particularly relevant for small farms, which are still working on the round system for farrowing. Under such a system, irregular use of boars and maintenance personnel, low turnover of machine spaces, overspending of feed and other production materials are noted. The main purpose of this work is the development of new volumetric-planning and technological decisions in the conditions of transfer of breeding enterprises from the round to the current production system with the determination of efficiency of rearing pedigree and repair of young pigs. The methodological basis was the theory and practice of technological and economic research on the improvement of technology of production of pig breeding products based on the introduction of modern volumetricplanning decisions for the reconstruction of new technological approaches to the production process. In the course of the research, a technological model of transfer of farms from a round to a current system of farrowing was developed and implemented. Design and technological solutions have been developed and their application in the reconstruction of the premises and transfer of the farm to the current system of obtaining farrows have been substantiated. The developed method of the current production is characterized by the fact that in order to reduce the age difference of piglets when applying a large rhythm step (more than 21 days), the operation of the rhythm step up to 7 days is performed, which ensures the rhythmic forma-
\end{abstract}

\footnotetext{
${ }^{1}$ Candidate of Agricultural Sciences, Deputy Director for Science, Institute of Pig Breeding and Agroindustrial Production of the National Academy of Agrarian Sciences of Ukraine, Ukraine

${ }^{2}$ Candidate Of Agricultural Ciences, Chief of Laboratory of Livestock Objects, Institute of Pig Breeding and Agroindustrial Production of the National Academy of Agrarian Sciences of Ukraine, Ukraine
} 
tion of technological groups and receiving farrows in optimal terms with a relatively aligned litter at within the technology group. The transfer of pedigree enterprises from round to current production technology with simultaneous reconstruction of premises and entry into a predetermined rhythm of production contributed to the increase of the main indexes of pig productivity, namely: litter weight in 60 days (by 25.0\%), number of farrows (by $25.5 \%$ ), average daily gain of suckling piglets (by $18.6 \%$ ), weaned pigs (by $31.3 \%$ ), fattening young animals (by $26.2 \%$ ), pedigree young animals (by 19.7\%). The introduction of new volumetric-planning and technological decisions reduced the use of the total production area of the premises for sows by 63.4-65.1 m2, increased the efficiency of the use of farrowing machines by 5-6 times and increased the intensity of the use of sows by $26-35 \%$. After the transfer to the current production technology in the SE "EE imeni Dekabrystiv "with a reduction of 36 heads of the main sows, the number of pigs increased by $12 \%$, the output of piglets per 100 main sows increased by 552 heads, the production of pork per main sow increased by $12.7 \%$, the average daily gain of pigs increased from 389 up to $428 \mathrm{~g}$. In SE "Stepne", with the same number of maternal livestock, the number of pigs increased by $18.6 \%$, the average daily increase - by $15.2 \%$, the output of piglets per 100 main sows increased by 992 heads. and increase pork production by one main sow to $431 \mathrm{~kg}$.

\section{Introduction}

The issue of the improvement of rearing pedigree and repair young pigs in modern technologies is particularly relevant for small farms, which are still working on the round system for receiving farrows. The work on increasing the profitability of pedigree and commercial pig breeding should be based on modern economically justified low-cost technologies [1, p. 49; $4 ; 8$, p. 33]. On this basis, the enterprises should concentrate their activity in finding ways to improve and realize production and marketing opportunities $[3$, p. 126; 5]. The topical directions of increasing the economic efficiency of business activities in pig breeding can be considered: improvement of the system of housing animals; rationalization of the feeding system; formation of a qualitative breeding base of pig breeding $[2 ; 6, p .9]$. Despite the steady progress in pig breeding in Ukraine, most breeding factories that are not part of the large industrial complexes carry out their work on a round or 
seasonally round system of receiving farrows. Under these conditions, the main offspring are obtained in relatively comfortable spring and summer conditions, which allows to rear a strong and promising breeding stock in terms of use in the breeding process. However, such a system of work in enterprises shows irrational use of boars and maintenance staff, low turnover of machine spaces, over-consumption of feed and other production materials. As the maternal stock to receive farrows in spring and summer and autumn has a forced idle time, the management of such technology impedes the efficiency of using the maternal stock and the sale of reared young pigs. The transition to new progressive forms of pig breeding with a current-based system of receiving farrows is primarily constrained by the fact that having a small number of basic sows makes it difficult to form efficient technological groups and, as a consequence, production facilities are scattered in their service, and the presence of small technologically diverse pig groups requires special conditions for housing, feeding and care. The transition to the use of new technological approaches is also conditioned by the lack of experience of transferring pedigree enterprises from round to a current-based system of receiving farrows. There are also almost no data on the features of the farm premises reconstruction with such technologies, so that the created conditions take into account the biological features of the age-old livestock as much as possible. In addition, a market economy requires the development and implementation of energy and resource-saving technologies using new types of facilities for the production of breeding and commercial pig production. Under this approach, the reconstruction can be undertaken to address the following issues: improving pig feeding through the use of new, effective, fully-fledged compound feeds that maximize the genetic potential of animals; modernization of the equipment for pig housing all technological groups with modern means of feeding; improvement of own perspective breeds, types and lines due to enrichment with imported genotypes and improvement of breeding work; modernization of ventilation and creation of optimal microclimate during the whole period of rearing pigs; gradual replacement of the hydro-flushing system of manure removal on self-alloy with the equipment of machine tools with modern slot floors. Therefore, the development of new technological approaches to the reconstruction of pig farms and the transfer of breeding farms to a stream production system is relevant and has considerable the- 
oretical and practical interest. The main purpose of this work is to develop new volumetric-planning and technological solutions in the conditions of transfer of pedigree enterprises from the round to the stream production system and to determine the efficiency of breeding and repair of breeding pigs by modern technologies.

\section{Survey methodology}

The methodological basis was the theory and practice of technological and economic research on improving the work of enterprises made on the basis of the implementation of modern volumetric-planning desecions for the reconstruction of new technological approaches to conducting the production process. The main tasks in the development of new volumetric-planning and design-technological decisions for the reconstruction of premises were: to unlock the genetic potential of the maternal and fattening livestock to create comfortable conditions for housing animals under new technological solutions; search for new approaches to the development of pre-project proposals for the reconstruction of premises for the housing of animals, taking into account new parameters of their productivity; optimization of placement of machine equipment and division of premises into technological blocks for housing animals of different technological groups; providing recommendations for replacing the scraper slurry removal system with modern closed-type self-alloys; introduction of year-round control systems to ensure optimal microclimate; maximizing the use of natural lighting, modern thermal materials and the introduction of energy-efficient space heating technologies. The research material was a herd of the Large White and Myrgorod breeds of pigs and breeding technology for pedigree pigs in traditional premises with a round system for receiving farrows. The research was carried out in two directions: 1)analysis of the work of pedigree enterprises and the development of technological and economic bases for the transfer of pedigree enterprises from the round to the current system of receiving farrows; 2) development of volumetric-planning and design-technological decisions for the construction of modern farms for the production of pedigree pig breeding products. In the first direction of research the work was carried out in two stages. At the first stage, the analysis of existing technologies for breeding the pedigree pigs in SE "EE Stepne" and SE "EE imeni Dekabrystiv" and it has been devel- 
oped the technology for the current production of pork with new volumetric-planning decisions for the reconstruction of pig premises. At the second stage of the work after the reconstruction of farm premises was carried out according to the volumetric-planning decisions, it was curried out the transfer of pig breeding field in enterprises into to a current system of receiving farrows and evaluated the fattening, meat, reproductive qualities of pigs and technological and economic indicators for new production conditions. In the article it is presented the results of the implementation of the developed volumetric-planning and technological decisions in changing the technology of housing and the efficiency of the introduction of current technology in the State enterprises of experimental enterprises (SE EE) "Stepne", "imeni Dekabrysty "and" 9 Sichnia", which are part of the research enterprises of the National Academy of Agrarian Sciences of Ukraine.

\section{Results of own research}

Research was focused on the development of a new technological model for the transfer of pedigree enterprises from seasonal-round to the all year current rearing pedigree and fattening pigs with the use of new volumetric-planning and technological decisions. According to the research topic, the work was carried out in two stages. At the first stage, the enterprise were surveyed, the existing technologies of breeding pig production in SE "Stepne" and SE "SE. Decembrists", developed the technological and economic basis for the transition of tribal enterprises from the round to the current system of receiving farrows. In the second stage, technologies for the current production of pork were developed for each enterprise, with new volumetric-planning decisions for the reconstruction of pig premises. In all enterprises which were studied, a seasonal-round system of farrows was applied, during which 1.7-1.8 farrows per sow were obtained during the year. With this technology, the production cycle was 6 months: 4 months - idle and dusty and 1.5-2 months - feeding period. In all the farms studied, a seasonal-tour system of farrowing was applied, during which 1.7-1.8 farrowings per sow were obtained during the year. With this technology, the production cycle was 6 months: 4 months - idle and dusty and 1.5-2 months - feeding period. On the basis of the conducted scientific researches, for the first time in the conditions of production of pedigree products, a technological model of transfer of a farm from a round to a cur- 
rent system of reciving farrows was developed and introduced. Design and technological solutions have been developed and their application in the reconstruction of the premises and transfer of the farm to the current system of obtaining farrows have been substantiated.

\section{Effectiveness of introduction of current technology in SE EE "Stepne"}

The analysis of the existing technology of rearing pedigree pigs showed that in the State Enterprise "Stepne" of Poltava district of Poltava region all premises where pigs were housed, equipped with conveyors for removal of TSN-2B manure, carts for distribution of forages like UTR, teat self-priming. Indoor ventilation is natural with the help of exhaust mines. With seasonal-round technology of receiving of farrows created a situation where, at the end of the production cycle, the farm contained almost 1000 heads of fattening pigs that the sausage shop was unable to process. The realization of commercial livestock with live weight at meat processing enterprises led to a loss of profit and loss of production of products of pig breeding. The pig live-stock of the pedigree factory of the SE EE "Stepne" were housed in six premises: in the first - boars (20 heads) and single sows, in the second pregnant sows, in the third, fourth and fifth - lactating sows and weaned piglets, in the sixth - fattening young pigs. The floor area in the lactating sow machine was $7 \mathrm{~m}^{2}$, on the pregnant sow $-2.5 \mathrm{~m}^{2}$, at the idle sow $1.2 \mathrm{~m}^{2}$, for the young pigs $-0.9-1 \mathrm{~m}^{2}$. The main task of the pedigree factory is to breed the pedigree young pigs, but due to seasonality of farrowing and unregulated demand, the farm sold only $12 \%$ of the pedigree stock and the rest of the high-quality pedigree stock was forced to sell as commodity. Productive indexes of pigs for reconstruction are given in Table 1.

In the course of the research, a comparative study of the impact of technological approaches on the reproductive indexes of pigs was carried out for the first time and the results confirmed the feasibility of the proposed measures in the transition from round to the current system of production in pedigree enterprises. The introduction of the developed model of the current production and introduction of artificial insemination ensured the rhythmic formation of technological groups of single sows in 21 day increments, their insemination within 7 days and obtaining farrowing in the optimum time. The current-shop pork production technology always implies a high level 
Indexes of the productivity of pigs before reconstruction

\begin{tabular}{|l|c|}
\hline \multicolumn{1}{|c|}{ Indicators } & Value \\
\hline Pigs received in a year, heads & 278 \\
\hline Average multiplicity, heads & 3041 \\
\hline The total weight of weaned piglets, kg & 10,9 \\
\hline Loss, heads & 29227 \\
\hline Stuck, heads & 40 \\
\hline Transfer for repair, heads & 216 \\
\hline Transfer for fattening, heads & 188 \\
\hline The realized piglets in the group 0-2, heads & 1177 \\
\hline the Realized young pigs in group 2-4, heads & 429 \\
\hline Realized youngsters in group 2-4, goals & 905 \\
\hline Implemented breeding young animals, goals & 90 \\
\hline All realized, head & 1424 \\
\hline
\end{tabular}

of concentration of animals, a narrow specialization of premises and service personnel. Accordingly, the technologies developed were based on the following basic principles of current production: 1) the rhythm of receiving of offspring during each rhythm step; 2) year-round receiving farrows; 3 ) the formation of the required number of sows in the technological group and their synchronization; 4) placement of sows in groups according to their physiological condition, productivity, age and other factors; 5) adherence to accepted technology and duration of the reproductive cycle for the all stock of sows and the rejecting schemes; 6) clear production rhythm for all production groups. The reconstruction of the shop for the reproduction provided: development of a cycle diagram of current production of pedigree products, the use of artificial insemination, construction of an artificial insemination point. After an analysis of the work of the pedigree factory it has been developed the strategy for the effective reconstruction of pedigree enterprises without reducing the rate of reproduction of the herds. This process was accompanied by a number of tactical steps. At the first stage, a production program was developed to transfer the pedigree pig breeding of the pedigree factory of SE "EE" Stepne "to the current technology. The calculations and the developed cycle diagram showed that it was necessary to reconstruct the premises where the boars and sows were housed and to arrange artificial insemination of pigs. We have developed volumetric-plan- 
ning decisions for the point of artificial insemination and the premise for pigs with individual machines for housing sows and boars, and proposed a new method of feeding boars. Based on the calculations, the scheme of reconstruction (Figure 1) and the schedule of livestock movements of different technological groups (Figure 2) were proposed.

The peculiarity of the reconstruction was that for the first time we developed a method of the current production characterized in that in order to reduce the age variability of piglets, when using a large rhythm step (more than 21 days), the rhythm step operations are sealed, that is, the insemination of the technological group of idle sows takes place in short term - up to 7 days, the remaining 14 days of insemination does not occur.

Similarly, a technological group of lactating sows is formed within 7 days (with a deviation of \pm 2 days), but the sector closes only on the 21 st day, that is at the end of the rhythm step. Weaning of piglets also occurs within 7 days, and the remaining 14 days of piglets are housed in the same machines without sows, which minimizes the stress factor in weaned piglets. Then they are transferred to the rearing and fattening section. This technology allows pigs to be fattened in different ways. For example, in the case of small groups, the technological group of piglets is formed within a week. If you need to fatten a large group of animals, the formation is best done in one day. Changing the technology of production of pig products was carried out after the reconstruction and filling the premises with animals of different technological groups. According to the technology developed in the enterprise, the following technological operations were performed during the 21-day rhythm of the breeding factory by employees: at the precinct № 1 (the premise for housing boars and sows): to form a buffer group of single sows in the amount of 30 heads; to reject sows having two bays and transfer to the precinct № 5; to transfer infertile sows and sows after weaning pigs from section № 3, repair pigs from the fifth section and enter them into the buffer group; to select from the buffer group 30 sows in estrus, to transfer them into individual machines for insemination in a pig farm № 1; take sperm from 1-2 boars at the point of artificial insemination, check its quality, to dilute, to pack into vials and fertilize during seven days 30 sows housed in individual machines in a pig farm № 1; to identify with the help of the boar-sampler unfertilized sows (in estrus) (a pig farm № 1) and to transfer them into machines for re-insemination; transfer sows 


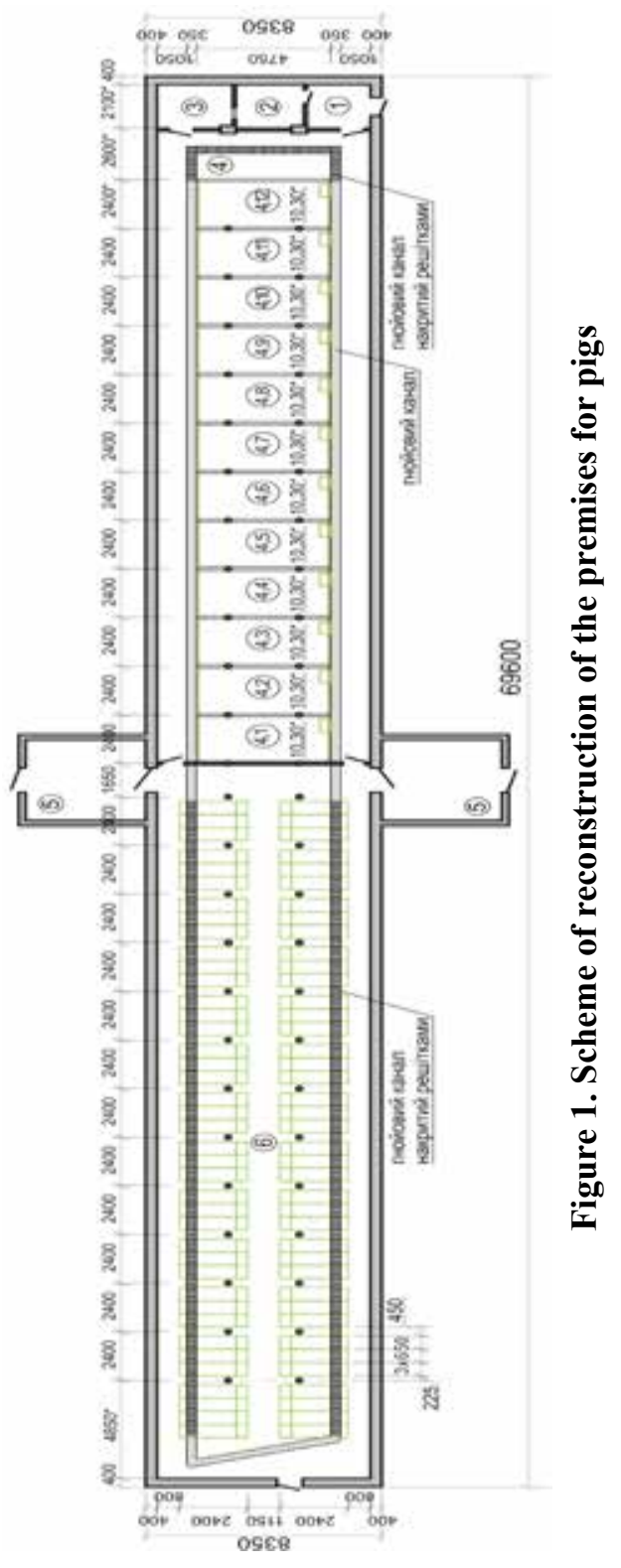




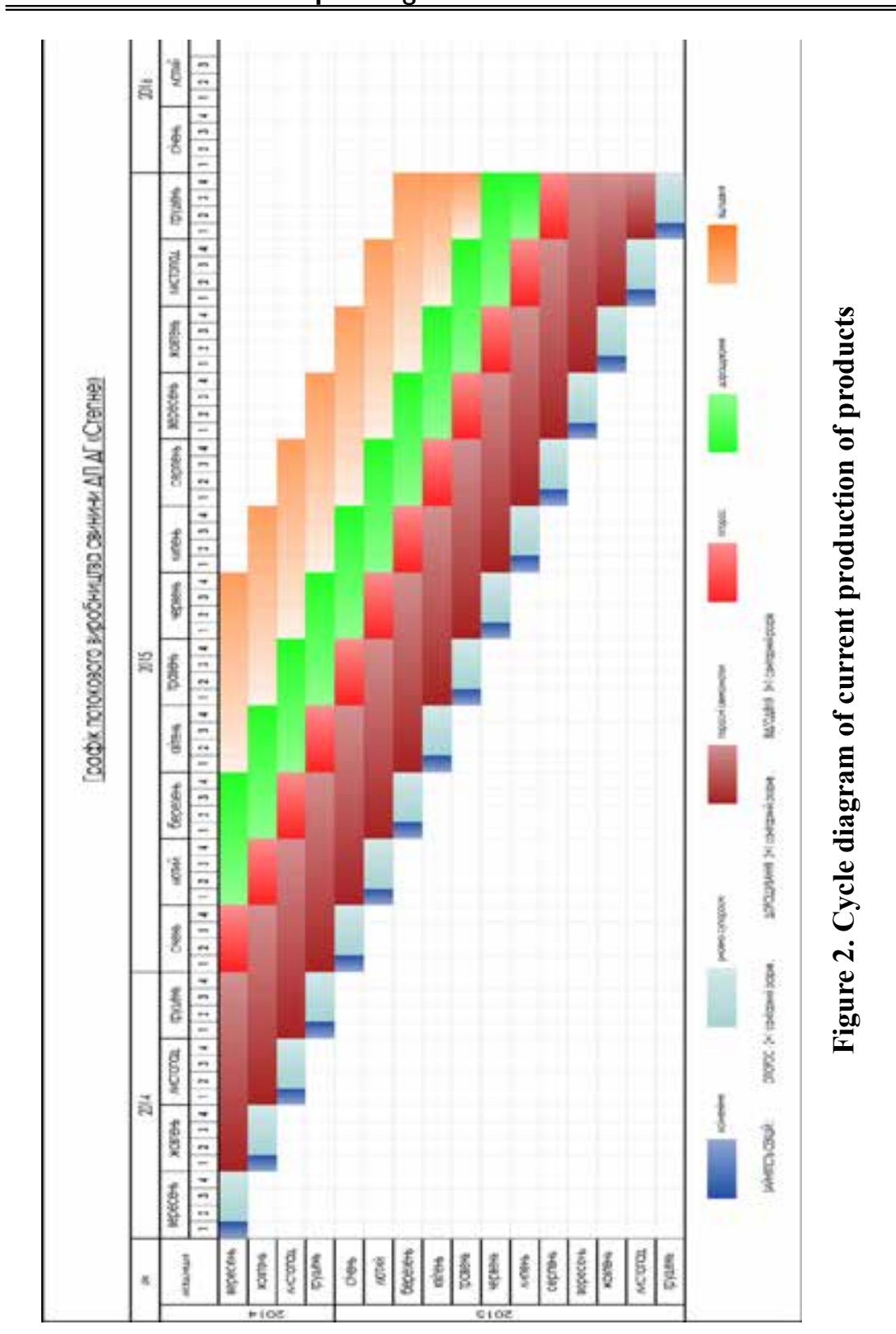


(after 32 days of conditional pregnancy) to the second section; to accept 2 repair boars from section №4; carry out repairs and disinfect discharged machines. At the precinct № 2 (a pig farm № 1): to place sows from the first section in group machines of 10 heads; identify unfertilized sows (main and inspected sows) and send for re-insemination to the precinct № 1; to select 25 sows of the second half of pregnancy (96 days of pregnancy) and transfer to the precinct № 3; carry out repair work and disinfect machine tools. At the precinct № 3 (pig farms № 2 and 4): to place 25 sows transferred from the precinct № 2 to the machines for 5-7 days before farrowing; to take a farrowing in sows, and after that to form a technological group of 24 lactating sows and suckling piglets; to wean sows from suckling pigltns in 28 days; to select the 22 best sows and transfer to the precinct №1, and transfer the selected sows to the precinct № 5, to remain the piglets to grow to 42 days; sort the technology group of 42-day-old piglets into 2 batches. One part to sell to the population, the other - to pass for fattening in a pig farm № 5 (the precinct № 5); carry out repair work and disinfect machine tools. At the precinct № 4 (a pig farm № 3): sort and place the repair young animals (boars and gilts); to transfer repair gilts and boars to the precinct № 1; send 2 boars for sale, or to castrate them and transfer for fattening (the precinct № 5); carry out repair work and disinfect machine tools. At the precinct № 5 (a pig farm № 5): to accept from section № 3 young pigs, to sort and place them in group machines on 25-30 heads; to accept sows having two absences from the precinct № 1; to accept low-productive sows from precinct № 3 and 2 castrated boars from precinct № 5; to send for sale breeding young pigs and ( unfertilized and rejected after lactation) adult sows; to reject the pigs and send them to slaughter; carry out repair work and disinfect machine tools. Table data. 2 indicate that as a result of reconstruction, the need for boars has decreased (by 3 times), for young boars (by 2.5 times), but the need for sows to be tested has increased (by 1.6 times).

Studies have shown the economic feasibility of transition of a pedigree farm to current technology of rearing of pigs. Thus, the change of the traditional round system of pork production to current increased rate of using sows from 1.8 to 2.0 , multiplicity from 11.5 to 12.3 heads per a sow, reduced piglet output: under the sow by $1.4-2.8$, on the rearing - by $0.4-0.8 \%$ (Table 3 ). Along with other indexes, pig interiors indexes have also improved, which has made them more attractive to sell. 
The structure of the herd of pigs before and after reconstruction

\begin{tabular}{|c|c|c|c|c|}
\hline \multirow{3}{*}{ Production group } & \multicolumn{4}{|c|}{ Livestock structure, $\%$} \\
\hline & \multicolumn{2}{|c|}{$\begin{array}{c}\text { before the } \\
\text { reconstruction }\end{array}$} & \multicolumn{2}{|c|}{ after reconstruction } \\
\hline & heads & $\%$ & heads & $\%$ \\
\hline Boars & 12 & 3,12 & 4 & 0,97 \\
\hline Main sows & 140 & 36,40 & 140 & 33,82 \\
\hline Checking boars & 3 & 0,80 & 4 & 0,97 \\
\hline Repair boars & 15 & 3,00 & 6 & 1,45 \\
\hline Cheking sows & 39 & 10,12 & 64 & 15,45 \\
\hline The gilts are over 4 months old & 176 & 45,71 & 196 & 47,34 \\
\hline
\end{tabular}

Table 3

Efficiency of using sows in the current technology of receiving piglets at the pedigree factory of SE "EE "Stepne"

\begin{tabular}{|l|c|c|c|}
\hline \multirow{2}{*}{\multicolumn{1}{|c|}{ Index }} & \multicolumn{2}{c|}{ indicator value } & \multirow{2}{*}{ To the basic, } \\
\cline { 2 - 3 } & basic version & New version & \pm \\
\hline $\begin{array}{l}\text { The intensity of using sows, } \\
\text { farrows per year }\end{array}$ & 1,8 & 2,0 & $+0,2$ \\
\hline Multiplicity of main sows, heads & 11,5 & 12,3 & $+0,8$ \\
\hline Leaning piglets under sow,\% & $2,5-3,9$ & 1,1 & $-1,4-2,8$ \\
\hline Leaning piglets on rearing,\% & $0,8-1,2$ & 0,4 & $-0,4-0,8$ \\
\hline
\end{tabular}

The annual economic effect obtained from the reconstruction of the premises under the new volumetric-planning decisions in the studied interprise amounted to UAH 54.7-56.1 thousand, or UAH 273-400. per 1 main sow.

\section{Effectiveness of the introduction of current technology in the SE "EE imeni Dekabrystiv"}

The second pedigree factory, where a study was carried out on the efficiency of the farm's transfer to a new technological scheme of production of pig breeding products, was in the State Enterprise "EE imeni Dekabrystiv" in Myrhorod district, Poltava region. Analysis of existing technology of rearing pedigree pigs showed that prior to the start of work on changing the technology of production of pig breeding products and the transfer 
of the farm from a round to a current system for receiving farrows, pigs were housed in five premises, where mechanical removal of manure using TSN conveyors was used. $2 \mathrm{~B}$, and the microclimate was maintained by natural supply and exhaust ventilation. Feeding pigs was carried out with wet crossbreds. The main live- stock of pigs was fed compound feed of its own production using premixes of AGRO-FID. Design and technological parameters and volumetric-planning decisions for the farm reconstruction were developed for the farm, which included partial redevelopment of the premises for housing lactating sows and piglets for rearing of Mirgorod breed of pigs and premises for breeding of hybrid pigs with the transfer of pig breeding field on current technology of production. During the reconstruction of the farm, a new production technology was based on a current production system for receiving pedigree and commercial pork. Under the new project, at the first stage of the pig farm's transition to a current system for receiving farrows and breeding pigs of Myrhorod breed, the premise for sows № 1 was divided into 2 blocks: the premise for sows for 36 machine places and a sector for rearing for 400 -seats (18 paired looms). For farrowings there are 3 sections on 12 machines (Figure 3 ). The turnover period of 1 section for farrowing is 42 days: 7 days the section is occupied by sows before farrowing; 28 days - suckling period; 7 days - sanitation of machines after weaning of piglets.

To obtain high-quality pork, increase meaty of carcass and provide the population with high-productive hybrid piglets for the economy, volumetric- planning decesions for the reconstruction of the pig premise № 5 were developed. According to the scheme, the point of artificial insemination of pigs with housing three boars (Duroc, Landrace and Peitren) is placed in front of the premises (Figure 4).

The general appearance of sections with machine tools for individual housing conditionally pregnant sows and group housing sows with defined pregnancy is shown in Figure 5.

The third section for $\mathrm{s}$ lactating sows with piglets has 48 individual machines and an automated feed system (left), and the fourth section for housing piglets for rearing is equipped with group machines with local heating (right) (Figure 6).

For automated distribution of feed, feed bunkers with rope-washer with giving feed to feeders are placed on a concrete platform near the pig premise 

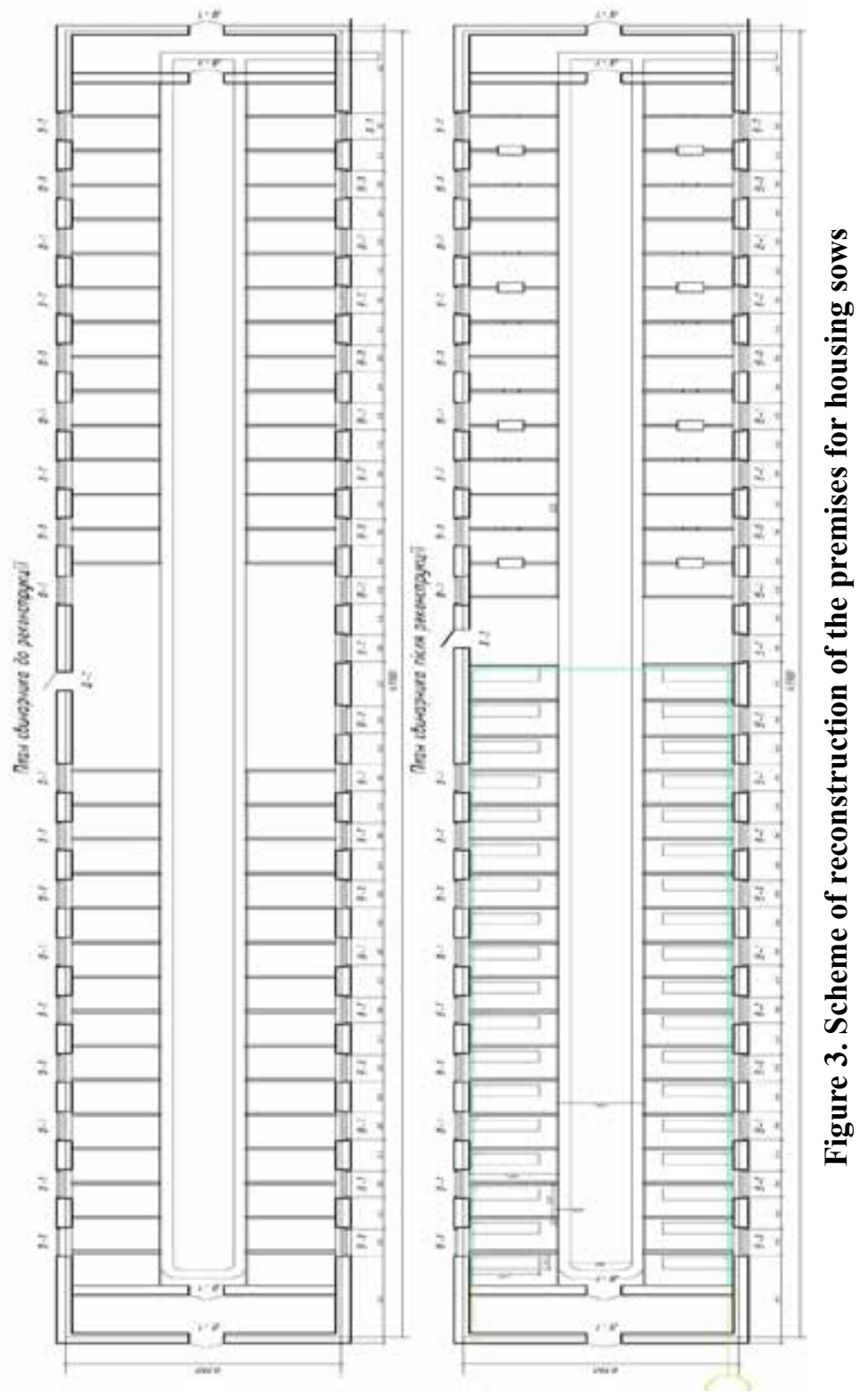
Serhii Smyslov, Mykhailo Sokyrko

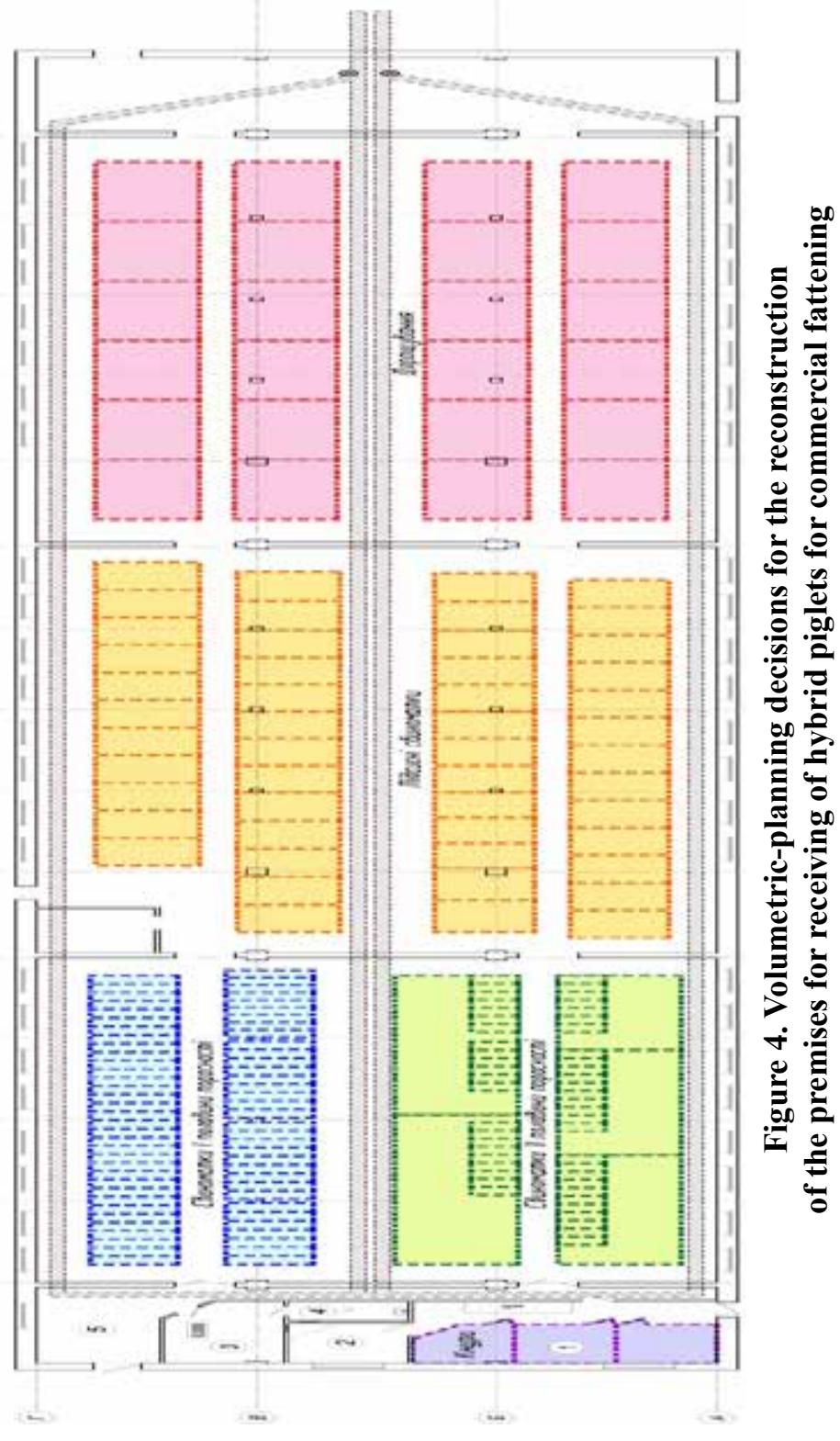




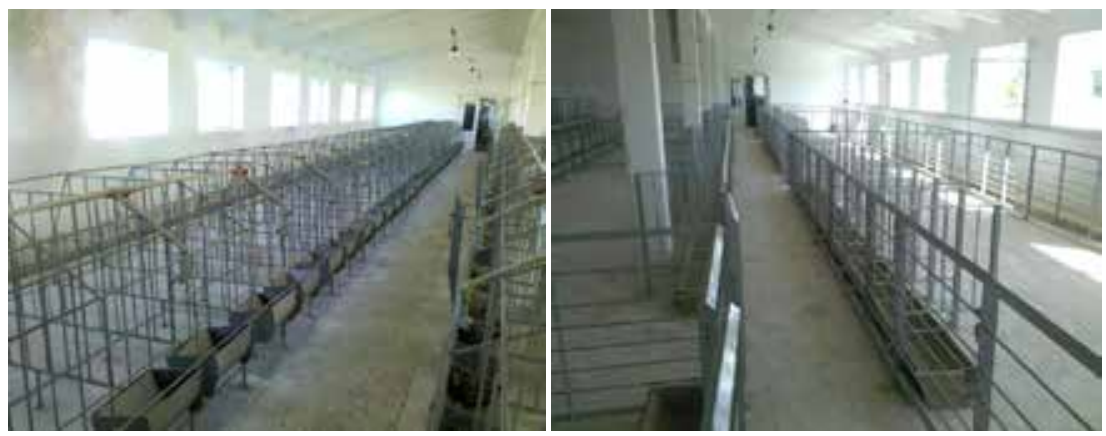

Figure 5. Housing conditionally pregnant sows (left) and sows with defined pregnancy (right)

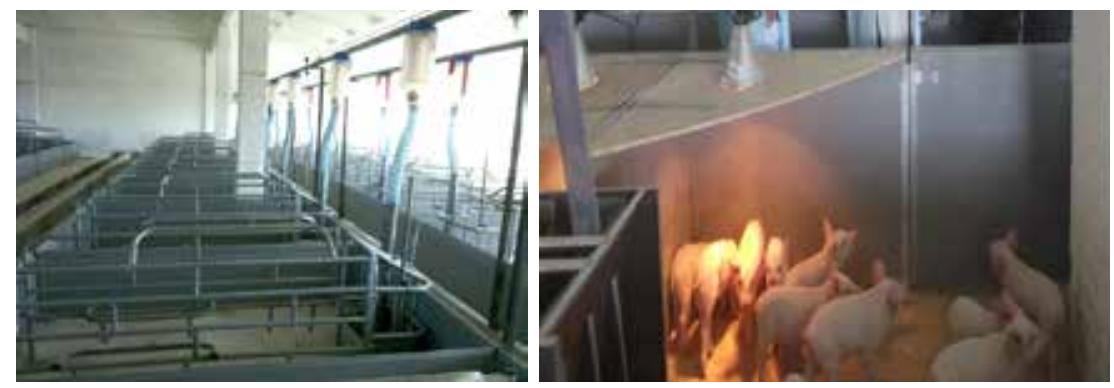

Figure 6. Fragment of the reconstructed premise for lactating sows with piglets (left) and fragment of retention machine for piglets on rearing with free-for-feed in feeders and a thermal comfort zone (right)

(Figure 7). Existing slurry channels were used to remove manure where new slurry was installed. Exhaust fans are installed to remove contaminated air.

Studies conducted on the development and implementation of new technological approaches have shown the economic feasibility of the transition of the pedigree farm from round to current technology of rearing pigs (table 4).

The installation of 36 machines for farrows ( 3 sections of 12 machines) allowed 84 sows to be used annually and to receive 51 piglets per year, which is 2 times more than with the use of basic (seasonal-round) technology. With a reduction of up to 28 days of suckling period, the intensity of sows usage increased from 1.7 to 2.1 farrowing per year, and the out- 


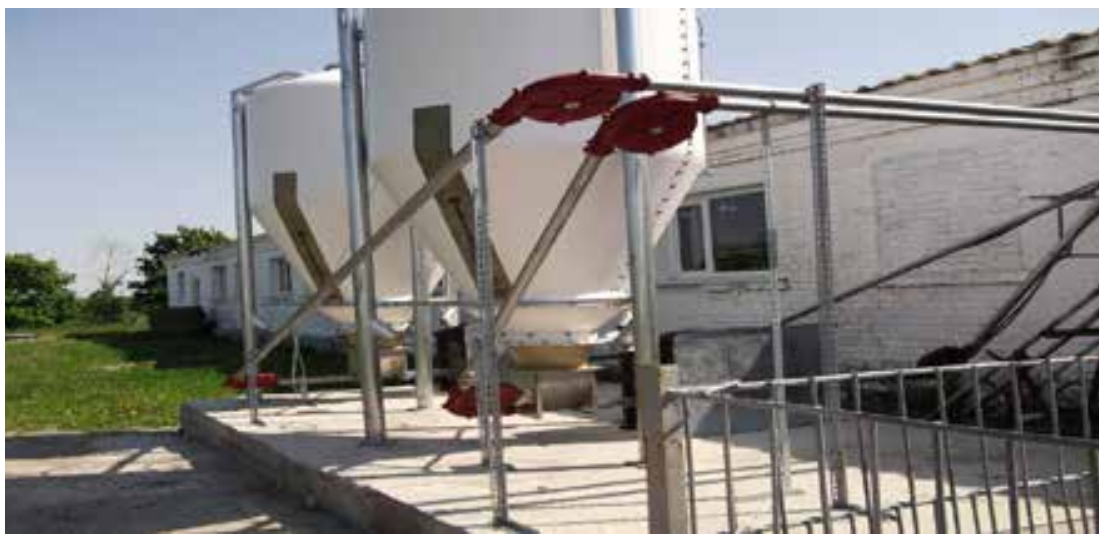

Figure 7. Bins for storage and giving feeds to the premises

Table 4

Technological and economic characteristics of the use of machine equipment for the premise for housing sows before and after the reconstruction at the pedigree factory in the SE "EE imeni Dekabrystiv"

\begin{tabular}{|l|c|c|c|}
\hline \multirow{2}{*}{\multicolumn{1}{|c|}{ Index }} & \multicolumn{2}{|c|}{ Indicator value } & \multirow{2}{*}{ To the basic, } \\
\cline { 2 - 3 } & $\begin{array}{c}\text { basic } \\
\text { version }\end{array}$ & $\begin{array}{c}\text { new } \\
\text { version }\end{array}$ & \pm \\
\hline Number of machines, pcs. & 60 & 36 & -24 \\
\hline Turnover of machines for a year, times & 2 & 8 & +6 \\
\hline Average annual use of easel equipment, days & 134 & 305 & +171 \\
\hline Number of sows, heads & 120 & 84 & -36 \\
\hline $\begin{array}{l}\text { Piglets were obtained for 1 farrowing } \\
\text { machine, heads }\end{array}$ & 24,6 & 51,0 & $+26,4$ \\
\hline $\begin{array}{l}\text { Business piglets (heads) were obtained for: } \\
\text { 1m }{ }^{2} \text { of production area }\end{array}$ & 4,5 & 5,9 & $+1,4$ \\
\hline 1st worker & 410 & 612 & +202 \\
\hline 1st sow & 15,8 & 21,8 & $+6,0$ \\
\hline
\end{tabular}

put of weaned pigs per 1 sow increased by 6 heads. The period of use of machines increased from 134 to 305 days, the annual output of business pigs increased by $1 \mathrm{~m}^{2}$ of production area by 1.4 heads, by 1 worker - by 202 heads [7, p. 221]. The new technology has improved the meat quality 
of pigs. According to the results of slaughter, animals of the experimental group had an average of $1.2 \mathrm{~cm}$ greater length of the half-carcass, on $4.5 \mathrm{~cm}^{2}$ of area of the "muscular eye" and on $0.4 \mathrm{~kg}$ of weight of the back third of the half-carcass. The thickness of the spike on the animal's shoulder was less than $5.5 \mathrm{~mm}$. The transfer to the current technology has improved the interior indexes of pigs. Studies have shown that the animals of the experimental group in comparison with the control analogues prevailed in such interior indexes as the content of protein in the blood (by $11.36 \%$; $p<0,05$ ), the area of the "muscular eye" (by $13,5 \%$; $p<0.05$ ). In our opinion, this is due to the adaptation processes that took place in the new animal habitat. Concerning the physical and chemical properties of meat and fat, our studies also found no significant difference between the experimental groups. This is understandable, since these indexes are largely dependent on genotypic rather than paratypical factors. Thus, when assessing the muscle tissue of fattening young animals by chemical parameters, no significant difference in the experimental groups in meat of the Large White breed was found between the content moisture, ash, protein, calcium and phosphorus). Total moisture was in the range of 74.28-74.42\%; ash - 1,26-1,33; protein $-22,4-22,5$ and fat $-1,19-1,22 \%$. An important qualitative factor in the culinary properties of pork is its ability to retain sufficient moisture. Meat that contains enough bound water - more juicy, has a softer texture, better aroma and taste. In the context of the experimental groups, the result on the moisture content was in the range - from 51.53 to $52.32 \%$. Equally important indexes is the color that characterizes the commodity meat's appearance and the technological properties of the meat. Analysis of the results for this index between the experimental groups of animals did not reveal a significant difference, it ranged from 62.33-63.01. The heat treatment losses in the animals of the experimental groups were almost the same. Based on the conducted research, it should be noted that the annual economic effect obtained from the reconstruction of the premises under the new volumetric-planning decisions in the State Enterprise "imeni Dekabrystiv" amounted to UAH 54.7 thousand, or UAH 273. for one main sow, and in the State Enterprise "EE "Stepne" - UAH 56.1 thousand or 400 UAH. per 1 main sow. The transfer of pedigree enterprises to the current production technology is the most appropriate in terms of efficient use of labor and material resources and implies a high level of intensity and economic efficiency of the industry. 
After the transfer to the current production technology in the SE "EE imeni Dekabrysty" with a reduction of 36 heads of the main sows, the number of pigs increased by $12 \%$, the output of piglets per 100 main sows increased by 552 heads, the production of pork per main sow increased by $12.7 \%$, the average daily gain of pigs increased from 389 up to 428 g. In SE "Stepne", with the same number of maternal livestock, the number of pigs increased by $18.6 \%$, the average daily increase - by $15.2 \%$, the output of piglets per 100 main sows increased by 992 heads. and increase pork production by one main sow to $431 \mathrm{~kg}$.

\section{Conclusions}

The analysis of pig production technologies in pedigree enterprises was carried out and new volumetric-planning desisions for the reconstruction of premises for rearing pedigree and repair young pigs during the transfer from the round to the current production system of allowed to increase the output of piglets per 1 sow and 1 worker. This increased the load per sow to 2.1-2.2 farrowing per year, while increasing the turnover of farrowing machines up to 8 times per year: 1 . The introduction of new volumetric-planning and technological decisions in the studied farms reduced the use of the total production area of the premises for sows by $63.4-65.1 \mathrm{~m}^{2}$, increased the efficiency of using the machines for farrowing by 5-6 times and increased the intensity by $26-35 \%$ use of sows. 2 . The developed method of the current production is characterized by the fact that in order to reduce the age difference of piglets when applying a large rhythm step (more than 21 days), the operation of the rhythm step up to 7 days is performed, which ensures the rhythmic formation of technological groups and obtaining farrows in the optimum time with relatively balanced litter within the technological group. 3. It has been determined that the transfer of pedigree enterprises from the round to current production technology with simultaneous reconstruction of premises and entry into a predetermined rhythm of production, allows to increase the multiplicity of sows to $12,1-12,3$ piglets per farrow, to increase the output of piglets by 100 main sows on $35.8-58.5 \%$, pork production per one main sow - by $12.7-35.0 \%$, and the number of breeding stock sold by $32-57$ percent. 4 . The use of the current technology for receiving farrows and the introduction of weaning piglets in 28 days, contributed to the increase of the main productive 
indexes of pigs, namely: the weight of the litter at 60 days (by $25.0 \%$ ), the number of farrows (by 25.5\%) average daily gain of piglets (by 18.6\%), weaned piglets (by $31.3 \%$ ), fattening young animals (by 26.2\%), breeding young animals (by 19.7\%). 5. The annual economic effect obtained from the reconstruction of the premises under the new volumetric-planning decisions in the studied farms amounted to UAH 54.7-56.1 thousand, or UAH 273-400. per 1 main sow.

\section{Offers to production}

In order to increase the efficiency of production of pedigree products of pig breeding, it is advisable to transfer pedigree enterprises operating on a season-round system of farrowing to the current technology of production of pig breeding products according to the developed model with the use of compacted farrowing at an extended rhythm step.

\section{References:}

1. Voloshchuk V.M. (2012). Teoretychne obgruntuvannya i stvorennya konkurentospromozhnykh tekhnolohiy vyrobnytstva svynyny: Monohrafiya [Theoretical substantiation and creation of competitive technologies of pork production]. Poltava: Techservice Firm, 48-51 pp. (in Ukrainian)

2. Voloshchuk V.M., Zamykula V.V., Smyslov S.Yu., Pidtereba O.I., Onyshchenko A.O. Tekhnolohiia vyroshchuvanniapleminnoho molodniaku svynei v umovakh plemzavodiv Poltavskoi oblasti [Technology of rearing pig breeding pigs in the conditions of breeding plants of Poltava region]. Access mode: http://www.stattionline.org.ua/agro/109/20609-texnologiyaviroshhuvannya-pleminnogo-molodnyaku-svinej-v-umovax-plemzavodivpoltavskoi-oblasti.html

3. Ivanov V.O., Dudchenko D.V., Voloshchuk V.M. (2008). Rekonstruktsiia na malykh fermakh [Reconstruction on small farms]: zb. nauk. pr. Instytutu tvarynnytstva «Askaniia-Nova». Vol. 1, 126 p. (in Ukrainian)

4. Koberniuk S.O. (2009). Napriamy vdoskonalennia vyrobnytstva produktsii svynarstva $\mathrm{v}$ Ukraini [Directions for improving pig production in Ukraine] [Electronic resource]. Access mode: http://www.rusnauka.com/25_NPM_2009/ Economics/51312.doc.htm (in Ukrainian)

5. Kolomiyets' S.M. Suchasnyy stan vyrobnytstva svynyny v Ukrayini i za kordonom [Current state of pork production in Ukraine and abroad]. Access mode: http://khntusg.com.ua/files/sbornik/vestnik_108/2.pdf

6. Lymar V.O., Voloshchuk V.M., Khatko I.V., Pidtereba O.I. (2012). Prohresyvni tekhnolohii u svynarstvi ta ikh perevahy [Advanced technologies in pig production and their benefits]. Interagency thematic scientific collection «Pig breeding», no. 60, pp. 8-11. (in Ukrainian) 
7. Pidteberba O.I., Smyslov S.Yu., Sokyrko M.P. (2013). Efektyvnist' novykh tekhnolohichnykh rishen' pry rekonstruktsii svynars'kykh pleminnykh ferm [The effectiveness of new technological solutions in the reconstruction of pig breeding farms]. Collection of scientific works of Podilsky State Agrarian and Technical University. Series "Technology of production and processing of livestock products". Kamianets-Podilskyi, vol. 21, pp. 221-222. (in Ukrainian)

8. Chertkov D.D. (2007). Naukove obhruntuvannia malovytratnoi tekhnolohii vyrobnytstva produktsii svynarstva $\mathrm{v}$ Ukraini [Scientific substantiation of low-cost technology of pig production in Ukraine]: author. diss. for the acquisition. Sciences. degree of Doctor of Agricultural Sciences Sciences: Special. 02/06/04 "Livestock Production Technology". Kiev, 25 p. (in Ukrainian) 